Cambridge University Press

978-1-107-10888-2 - Reinforcing Rule of Law Oversight in the European Union

Edited by Carlos Closa , Dimitry Kochenov

Frontmatter

More Information

\title{
REINFORCING RULE OF LAW OVERSIGHT IN THE EUROPEAN UNION
}

This book provides the definitive reference point on all the issues pertaining to dealing with the 'crisis of the Rule of Law' in the European Union. Both Member State and EU levels are considered. Particular attention is paid to the analysis of the concrete legal bases and instruments that the EU may avail of enforcing Rule of Law, and the volume clearly demonstrates that a number of legally sound ways of Rule of Law oversight are available. Contributors are leading scholars who assess the potential role to be played by the various bodies in the context of dealing with the EU's Rule of Law imperfections.

CARlos Closa is Professor of Political Science at Institute for Public Goods and Policies (IPP) at the Consejo Superior de Investigaciones Cientificas (CSIC), Madrid. He has been member of the Venice Commission for democracy through law and consultant for the Council of Europe, the European Commission and the European Parliament. He has researched and published widely, focusing on the areas of EU citizenship, the EU's constitutional structure, and relations between the EU and its member states.

Dimitry kochenov is Martin and Kathleen Crane Fellow in Law and Public Affairs at the Woodrow Wilson School, Princeton University (20152016); Professor of EU Constitutional Law in Groningen and Visiting Professor at the College of Europe, Natolin. He has advised international institutions and governments, including Dutch and Maltese. He has researched and published widely, focusing on EU constitutional law, EU citizenship, and EU overseas territories law. 


\title{
CAMBRIDGE
}

Cambridge University Press

978-1-107-10888-2 - Reinforcing Rule of Law Oversight in the European Union

Edited by Carlos Closa , Dimitry Kochenov

Frontmatter

More Information

\section{REINFORCING RULE OF LAW OVERSIGHT IN THE EUROPEAN UNION}

\author{
Edited by \\ CARLOS CLOSA \\ DIMITRY KOCHENOV
}




\section{CAMBRIDGE}

\section{Cambridge University Press}

978-1-107-10888-2 - Reinforcing Rule of Law Oversight in the European Union

Edited by Carlos Closa , Dimitry Kochenov

Frontmatter

More Information

\section{CAMBRIDGE UNIVERSITY PRESS}

University Printing House, Cambridge CB2 8BS, United Kingdom

Cambridge University Press is part of the University of Cambridge.

It furthers the University's mission by disseminating knowledge in the pursuit of education, learning, and research at the highest international levels of excellence.

www.cambridge.org

Information on this title: www.cambridge.org/9781107108882

(C) Carlos Closa and Dimitry Kochenov 2016

This publication is in copyright. Subject to statutory exception and to the provisions of relevant collective licensing agreements, no reproduction of any part may take place without the written permission of Cambridge University Press.

First published 2016

A catalog record for this publication is available from the British Library.

ISBN 978-1-107-10888-2 Hardback

Cambridge University Press has no responsibility for the persistence or accuracy of URLs for external or third-party Internet Web sites referred to in this publication and does not guarantee that any content on such Web sites is, or will remain, accurate or appropriate. 


\section{CONTENTS}

List of Figures page viii List of Contributors ix Preface xi List of Abbreviations $\quad$ xiii Table of Cases xiv

Introduction: How to Save the EU's Rule of Law and Should One Bother? 1 CARLOS CLOSA AND DIMITRY KOCHENOV

\section{PART I Establishing Normative Foundations 13}

1 Reinforcing EU Monitoring of the Rule of Law: Normative Arguments, Institutional Proposals and the Procedural Limitations $\quad 15$ CARLOS CLOSA

2 Beyond Legality - Before Democracy: Rule of Law Caveats in the EU Two-Level System 36

GIANLUIGI PALOMBELLA

3 Overseeing the Rule of Law in the EU: Legal Mandate and Means 59

CHRISTOPHE HILLION

4 Protecting Democracy inside the EU: On Article 7 TEU and the Hungarian Turn to Authoritarianism 82 BOJAN BUGARIČ 
5 Enforcing the Basic Principles of EU Law through Systemic Infringement Actions 105

KIM LANE SCHEPPELE

6 Mutual Trust: The Virtue of Reciprocity - Strengthening the Acceptance of the Rule of Law through Peer Review 133 ERNST HIRSCH BALLIN

7 The Rule of Law and the Role of Fundamental Rights: Seven Practical Pointers 147

GABRIEL N. TOGGENBURG AND JONAS GRIMHEDEN

8 The Potential of the EU Charter of Fundamental Rights for the Development of the Rule of Law Indicators MARTIN SCHEININ

9 The EU Charter of Fundamental Rights as the Most Promising Way of Enforcing the Rule of Law against EU Member States 187

ANDRÁS JAKAB

10 Protecting the Rule of Law (and Democracy!) in the EU: The Idea of a Copenhagen Commission 206

JAN-WERNER MÜLLER

11 From Copenhagen to Venice KAARLO TUORI

\section{PART III Identifying Deeper Problems}

12 EU Democratic Oversight and Domestic Deviation from the Rule of Law: Sociological Reflections

PAUL BLOKKER

13 Why Improve EU Oversight of Rule of Law?: The Two-Headed Problem of Defending Liberal Democracy and Fighting Corruption 270

MILADA ANNA VACHUDOVA 


\section{CAMBRIDGE}

Cambridge University Press

978-1-107-10888-2 - Reinforcing Rule of Law Oversight in the European Union

Edited by Carlos Closa , Dimitry Kochenov

Frontmatter

More Information

CONTENTS

14 The Missing EU Rule of Law?

290 DIMITRY KOCHENOV

Epilogue: Living in a Glass House: Europe, Democracy and the Rule of Law 313

J. H. H. WEILER

Index 327 


\section{CAMBRIDGE}

Cambridge University Press

978-1-107-10888-2 - Reinforcing Rule of Law Oversight in the European Union

Edited by Carlos Closa , Dimitry Kochenov

Frontmatter

More Information

\section{FIGURES}

1 Interlinks between the sets of standards in the European Union

2 Comparison between Article 2 TEU values and the Charter of

3 The 'structural - process - outcome' indicator framework

4 Schematic view of a fundamental rights cycle 
CONTRIBUTORS

\section{Paul Blokker}

Charles University, Prague; University of Trento, Department of Sociology

\section{Bojan Bugarič}

Center for European Studies, Harvard University; University of Ljubljana, Faculty of Law

\section{Carlos Closa}

Instituto de Políticas y Bienes Públicos (IPP); Consejo Superior de Investigaciones Científicas, CSIC

\section{Jonas Grimheden}

EU Fundamental Rights Agency, Vienna; Faculty of Law, Lund University

\section{Christophe Hillion}

Leiden University, Faculty of Law; University of Gothenburg, Department of Law; Swedish Institute for European Policy Studies, Stockholm; University of Oslo, Centre for European Law and Norwegian Institute of International Relations.

\section{Ernst Hirsch Ballin}

Amsterdam University, Faculty of Law; Tilburg University, Faculty of Law; Member of the Netherlands Advisory Council for International Affairs; Former Minister of Justice of the Netherlands

\section{András Jakab}

Hungarian Academy of Sciences, Budapest; Max Planck Institute for Comparative Public Law and International Law, Heidelberg 


\section{Dimitry Kochenov}

LAPA Fellow, Woodrow Wilson School, Princeton University (20152016); University of Groningen, Faculty of Law; College of Europe, Natolin

\section{Jan-Werner Müller}

Princeton University, Department of Politics

\section{Gianluigi Palombella}

Scuola Superiore Sant'Anna, Pisa; Università di Parma

\section{Martin Scheinin}

European University Institute, Florence, Law Department

\section{Kim Lane Scheppele}

Princeton University, Department of Sociology and Woodrow Wilson School

\section{Gabriel N. Toggenburg}

EU Fundamental Rights Agency, Vienna;University of Graz, Faculty of Law

\section{Kaarlo Tuori}

University of Helsinki, Faculty of Law; Member of the Venice Commission for Democracy through Law of the Council of Europe

\section{Milada Anna Vachudova}

University of North Carolina at Chapel Hill, Department of Political Science

\section{J. H. H. Weiler}

President, European University Institute, Florence 


\section{PREFACE}

What to do when the Rule of Law in the Union is apparently crumbling under pressure from Member States deviating from the foundational values on which the whole edifice of European integration rests? What kind of tools do we have at our disposal, able to go beyond the established Treaty mechanisms, which have seemingly been proved ineffective by the recent developments and ongoing persistence of fundamental deviations from EU norms? Should the EU be more proactive and why?

This book aims to discuss the normative issues related to the role of the EU in the Rule of Law enforcement field and to list and scrutinise innovative tools of potential use for the Union in asserting its own values. The key scholars behind virtually all the most important proposals have participated in this volume to outline their position firsthand. In addition, the book also considers and discusses the complexity of the broader landscape of European constitutionalism to warn against any course of action which would not be extremely carefully thought over, considering the key strengths and, crucially, also notable weaknesses of the EU's legalpolitical edifice.

This collection of essays aims at a broad, positive outline: there are tools to solve the outstanding problems, all the words of caution notwithstanding. The detailed presentation of these tools is the core mission of this book and its key added value as we designed it. Where there are many proposals, there are bound to be many disagreements - such is life. The editors fully realise this, and one of the key strengths of the book was allowing the participating scholars to engage with each other's methods for overcoming the common problem, the assumption being that such a dialogue, at times very polemical, will result in a more comprehensive description of the key avenues for Reinforcing Rule of Law Oversight in the European Union.

The project thus started with a vivid meeting of the majority of the contributing scholars at the European University Institute in Florence at a one-day seminar co-sponsored by the EUI and University of Groningen, 
which occurred in January 2014 and was opened by the EUI President, Professor J. H. H. Weiler. All the chapters have been profoundly updated and reworked since then, so this book should not be regarded in any sense as a set of conference proceedings. ${ }^{1}$ We are overwhelmingly grateful to the Global Governance Program at the Robert Schuman Centre for Advanced Studies of the Institute as well as to the Groningen Centre for Law and Governance for co-sponsoring the event, and to all those colleagues who participated in the seminar without contributing a chapter, including but not limited to: Laszlo Bruszt, Clare Kirkpatrick, Brigid Laffan, and Bruno de Witte, as well as our assistants who worked with us on this project at different stages, in particular Elena Basheska, Martijn van den Brink, Ryan Chavez, Justin Lindeboom, Harry Panagopoulos, and Suryapratim Roy. Grisha Kochenov painted the blue-wheeled whale of the EU for the cover.

The book does not aim to be merely a piece of academic scholarship detached from the perils and problems of the 'real' world. Rather, concerns with events in some European states have prompted reflections on possible action with a clear guideline: the Rule of Law, democracy and human rights should not be taken as a foregone conclusion within the EU. A time during which thousands of people are fleeing conflict and die trying to reach European shores while some European states are busy dismantling their democracy and Rule of Law guarantees reminds us that engagement with values should not be a mere and empty exercise of academic rhetoric and eloquence but should be meaningful to the lives of the persons whose welfare depends precisely on the stringent enforcement of these values. We therefore make a case for Union action, list its tools, but voice a note of caution against overestimating the Union's abilities. As you will notice, it is up to the reader to choose the most convincing tool for herself: this collection is a cookbook without a suggested menu, which is, we believe, also one of its strengths.

C.C., D.K. Florence and Princeton

\footnotetext{
1 The main outcome of the seminar was an EUI working paper, which is a natural accompanying text to this volume: C. Closa, D. Kochenov and J. H. H. Weiler, 'Reinforcing Rule of Law Oversight in the European Union', EUI Working Paper No. 2014/25, RSCAS.
} 
Cambridge University Press

978-1-107-10888-2 - Reinforcing Rule of Law Oversight in the European Union

Edited by Carlos Closa , Dimitry Kochenov

Frontmatter

More Information

\section{ABBREVIATIONS}

$\begin{array}{ll}\text { CFR } & \text { Charter of Fundamental Rights of the EU } \\ \text { CJEL } & \text { Columbia Journal of European Law } \\ \text { CMLRev } & \text { Common Market Law Review } \\ \text { CRPD } & \text { UN Convention on the Rights of Persons with Disabilities } \\ \text { ECHR } & \text { European Convention on Human Rights } \\ \text { ECJ } & \text { Court of Justice of the European Union } \\ \text { EJIL } & \text { European Journal of International Law } \\ \text { ELJ } & \text { European Law Journal } \\ \text { ELRev } & \text { European Law Review } \\ \text { EUConst } & \text { European Constitutional Law Review } \\ \text { FRA } & \text { Fundamental Rights Agency of the European Union } \\ \text { HRQ } & \text { Human Rights Quarterly } \\ \text { I-CON } & \text { International Journal of Constitutional Law } \\ \text { ICLQ } & \text { International and Comparative Law Quarterly } \\ \text { JCMS } & \text { Journal of Common Market Studies } \\ \text { JEPP } & \text { Journal of European Public Policy } \\ \text { ODIHR } & \text { OSCE Office for Democratic Institutions and Human Rights } \\ \text { OJLS } & \text { Oxford Journal of Legal Studies } \\ \text { OSCE } & \text { Organisation for Security and Cooperation in Europe } \\ \text { TEU } & \text { Treaty of European Union } \\ \text { TFEU } & \text { Treaty on the Functioning of the European Union } \\ & \end{array}$




\section{CAMBRIDGE}

Cambridge University Press

978-1-107-10888-2 - Reinforcing Rule of Law Oversight in the European Union

Edited by Carlos Closa , Dimitry Kochenov

Frontmatter

More Information

TABLE OF CASES

\section{European Union (Supranational Courts)}

26/62 NV Algemene Transporten Expeditie Onderneming van Gend en Loos v.

Nederlandse Administratie der Belastingen ECLI:EU:C:1963:1 [1963] ECR 1 (special

English edition), 36, 319

6/64 Flaminio Costa v. ENEL ECLI:EU:C:1964:66 [1964] ECR 585, 37, 304

294/83 Partie Ecologiste 'Les Verts' v. Parliament ECLI:EU:C:1986:166 [1986] ECR

$1339, \quad 16,37,294$

Joined cases 46/87 and 227/88 Hoechst v. Commission ECLI:EU:C:1989:337 [1989]

ECR 2859, 70

5/88 Wachauf ECLI:EU:C:1989:321 [1989] ECR 2609, 70, 191

C-260/89 ERT ECLI:EU:C:1991:254 [1991] ECR I-2925， 70, 191

Opinion 1/91 EEA Agreement ECLI:EU:C:1991:490 [1991] ECR I-6097， 37, 292, 294

Case C-65/93 Parliament v. Council (GSP) ECLI:EU:C:1995:91 [1995] ECR I-643, 63

C-309/96 Annibaldi ECLI:EU:C:1997:631 [1997] ECR I-7493， 70, 191

C-292/97 Kjell Karlsson and Others ECLI:EU:C:2000:202 [2000] ECR I-2737， 70, 191

T-33/09 Portugal v. Commission ECLI:EU:T:2011:127 [2011] ECR II-1429, 129

C-494/01 Commission v. Ireland (Irish Waste) ECLI:EU:C:2005:250 [2005] ECR I-3331,

$111,112,113$

C-441/02 Commission v. Germany ECLI:EU:C:2006:253 [2006] ECR I-3449, 114

Opinion 1/03 Lugano ECLI:EU:C:2006:81, 63

C-266/03 Commission v. Luxembourg ECLI: EU:C:2005:341, 63

C-433/03 Commission v. Germany ECLI:EU:C:2005:462, 63

C-144/04 Mangold ECLI:EU:C:2005:709, 230

C-156/04 Commission v. Greece ECLI:EU:C:2007:316, 114

C-135/05 Commission v. Italy ECLI:EU:C:2007:250, 111, 113

C-342/05 Commission v. Finland ECLI:EU:C:2006:752, 114

C-380/05 Centro Europa ECLI:EU:C:2008:59, 93, 193

Joined cases C-402 and 415/05P, Kadi \& Al Barakaat International Foundation v.

Council \& Commission ECLI:EU:C:2008:461, 37, 39, 50

C-88/07 Commission v. Spain ECLI:EU:C:2009:123, 111, 113

C-416/07 Commission v. Greece ECLI:EU:C:2009:528, 114 


\section{CAMBRIDGE}

Cambridge University Press

978-1-107-10888-2 - Reinforcing Rule of Law Oversight in the European Union

Edited by Carlos Closa , Dimitry Kochenov

Frontmatter

More Information

C-518/07 Commission v. Germany ECLI:EU:C:2010:125, 115

C-550/07P Akzo Nobel Chemicals and Akcros Chemicals v. Commission ECLI:EU:C:2010:229, 70

C-555/07 Kücükdeveci ECLI:EU:C:2010:21, 70

C-135/08 Janko Rottmann ECLI:EU:C:2009:588， 49, 195, 304

C-160/08 Commission v. Germany ECLI:EU:C:2010:230, 114

C-34/09 Ruiz Zambrano ECLI:EU:C:2010:560, 49, 192, 195, 228, 229

C-434/09 McCarthy ECLI:EU:C:2011:277， 229, 304

C-81/10 P France Télécom v. Commission ECLI:EU:C:2011:811, 67

Joined cases C-411/10 N.S. v. Secretary of State for the Home Department and C-493/10

M.E. and Others v. Refugee Applications Commissioner and Minister for Justice,

Equality and Law Reform ECLI:EU:C:2011:865, 27, 139, 231, 292, 307, 308, 309

C-614/10 Commission v. Austria ECLI:EU:C:2012:631, 115

C-617/10 Åklagaren v. Åkerberg Fransson ECLI:EU:C:213:280, 192, 196, 198, 230

C-4/11 Germany v. Kaveh Puid ECLI:EU:C:2013:740, 27

C-34/11 Commission v. Portugal ECLI:EU:C:2012:712, 114

C-68/11 Commission v. Italy ECLI:EU:C:2012:815, 114

C-256/11 Dereci ECLI:EU:C:2011:734， 229, 304

C-583/11 P Inuit Tapirit Kanatami and Others v. Parliament and Council

ECLI:EU:C:2013:625, 62

C-643/11 LVK ECLI:EU:C:2013:55, 67

C-658/11, European Parliament v. Council ECLI:EU:C:2014:2025, 66

C-286/12 Commission v. Hungary ECLI:EU:C:2012:687, 74, 85, 96, 109, 234, 307

C-288/12 Commission v. Hungary ECLI:EU:C:2014:237， 74, 85, 105, 115, 116, 120 , 121,234

C-294/12 Abdullahi v. Bundesasylamt ECLI:EU:C:2013:813, 307

Joined cases C-488/12 to C-491/12 and C-526/12 Nagy and Others

ECLI:EU:C:2013:703, 201

Opinion 2/13 EU Accession to the ECHR (No. 2), ECLI:EU:C:2014:2454, 2, 61, 194, 233, 292, 300, 309, 310

C-146/13 Spain v. European Parliament and Council ECLI:EU:C:2015:298， 69

C-147/13 Spain v. Council ECLI:EU:C:2015:299, 67

C-206/13 Siragusa ECLI:EU:C:2014:126, 193

C-409/13 Council v. Commission ECLI:EU:C:2015:217, 63

C-505/13 Levent Redzheb Yumer ECLI:EU:C:2014:2129, 69

C-542/13 Mohamad M'Bodjv. Belgium ECLI:EU:C:2014:2452, 310

\section{European Court and Commission of Human Rights}

M.S.S. v. Belgium and Greece (application no. 30696/09), 20, 139, 307

Horváth and Kiss v. Hungary (application no. 11146/11), 119

Baka v. Hungary (application no. 20261/12), 116, 234 


\section{CAMBRIDGE}

Cambridge University Press

978-1-107-10888-2 - Reinforcing Rule of Law Oversight in the European Union

Edited by Carlos Closa , Dimitry Kochenov

Frontmatter

More Information

$\mathrm{xvi}$

TABLE OF CASES

S.J. v. Belgium (application no. 70055/10), 310

Tarakhel v. Switzerland (application no. 29217/12), 307

\section{Other Courts and Tribunals}

Missouri v. Holland (1920) 252 U.S. 416, 38

Honeywell BVerfG, 2 BvR 2661/106, 6 July 2010, 230

Counter-terrorism database BVerfG, 1 BvR 1215/07, 24 April 2013, 230 